\title{
Mechanistic Understanding of Contact Allergy
}

\author{
Stefan F. Martin
}

Department of Dermatology, Medical Center, University of Freiburg, Hauptstrasse 7, 79104 Freiburg, Germany; stefan.martin@uniklinik-freiburg.de; Tel.: +49-761-270-67380; Fax: +49-761-270-66550

Academic Editors: Emanuela Corsini and David Basketter

Received: 20 January 2016; Accepted: 22 February 2016; Published: 25 February 2016

\begin{abstract}
Cosmetic products contain potential contact allergens or precursors that require metabolic conversion or oxidation to generate contact allergens. The most relevant contact allergens are fragrances and preservatives. These substances can pose hazards to human health due to their ability to activate $\mathrm{T}$ cells that can cause allergic contact dermatitis, an inflammatory skin disease. In recent years, much progress has been made in the elucidation of the mechanistic basis for immune system activation by contact allergens. This is essential for the development of better diagnostic tools, targeted therapies and animal-free in vitro assays for contact allergen identification. This overview will highlight some aspects of the activation of innate and adaptive immune responses by contact allergens.
\end{abstract}

Keywords: contact allergen; skin; innate immune response; heterologous innate immunity; biomarkers; therapy; in vitro assay; dendritic cell; $\mathrm{T}$ cell

\section{Contact Dermatitis}

Contact allergens are small organic chemicals or metal ions. As such they are too small to be recognized by the immune system. Therefore, they are also called haptens (half-antigens) and are obligatory reactive (electrophilic or complex-forming). Some chemicals must be oxidized (pre-haptens) or metabolically converted (pro-haptens) to acquire chemical reactivity [1]. Chemical reactivity is the main feature that differentiates contact allergens from irritants. The latter are, for example, detergents such as sodium dodecyl sulfate (SDS) that cause irritant contact dermatitis (ICD) but fail to activate an adaptive immune response. They exert toxic effects on skin cells but also seem to evoke some aspects of the innate immune response. Contact allergens cause allergic contact dermatitis (ACD). The prevalence is high with $15 \%-20 \%$ of the general population sensitized to at least one contact allergen and $5 \%-10 \%$ developing clinically manifest disease at least once a year [2,3]. Occupational ICD and ACD are some of the most important occupational diseases [4,5]. Many chemicals are encountered in the workplace and can cause severe problems [6]. Moreover, cosmetic contact allergens, especially fragrances, preservatives and hair dyes are of great importance [7]. Given the prevalence of contact dermatitis and its impact on human health, the urgent need for the development of novel mechanism-based targeted therapies is obvious. In addition, the risks in handling and use of chemicals in the workplace and in consumer products must be communicated to raise awareness, and preventive measures must be taken in the first place to avoid ACD and ICD.

Sensitization to a contact allergen can occur upon first skin contact and involves the induction of an innate inflammatory immune response and, eventually, a contact allergen-specific $\mathrm{T}$ cell response [8,9]. Elicitation of ACD requires repeated skin contact with the same contact allergen and results in the recruitment of circulating contact allergen-specific $\mathrm{T}$ cells into the skin. Repeated skin contact with the contact allergen may be required at the level of sensitization and elicitation for consumer or occupational ACD to occur. The $\mathrm{T}$ cells are then activated when they recognize the contact allergen 
in the context of major histocompatibility complex (MHC) molecules on skin cells. They promote inflammation due to their cytotoxic effector function and secretion of cytokines such as IFN- $\gamma$ and IL-17 [10]. The immune response is then rapidly downregulated by regulatory $\mathrm{T}$ cells and other cells with immunoregulatory functions such as NKT cells $[9,11]$.

\section{Diagnosis of ACD}

Productive sensitization is clinically inapparent but can be diagnosed by the patch test [3]. In this in vivo test, test substances are applied to the back skin for 48 hours. If sensitization to a test chemical exists, a red eczematous skin reaction is seen in the specific test area. This ACD is caused by contact allergen-specific $\mathrm{T}$ cells of the sensitized individual that are recruited to the inflamed skin and exert their effector function such as cytotoxic activity against cells which present the contact allergen in the context of MHC molecules. The patch test is a very old method that requires reading by trained and experienced experts. One future goal is the identification of, ideally, circulating biomarkers that unequivocally identify ACD and allow its distinction from ICD and from other forms of eczema. Recent studies are pointing in this direction. Here, global profiling technologies were used to identify contact allergen-specific or eczema subtype-specific gene signatures using human skin biopsies. The comparison of different contact allergens revealed commonly regulated genes but also genes that are specific for individual allergens [12]. The intra-individual comparison of patients with psoriatic, atopic or nickel-induced eczema also revealed gene signatures that are common or specific for the eczema subtype [13]. The identification of allergen- and disease-specific biomarkers will pave the way for modern, molecular diagnostics. Moreover, such studies will identify novel potential drug targets for causative therapies.

\section{Chemical Reactivity and Immune System Activation}

Contact allergens are reactive low molecular weight organic chemicals or metal ions. Their reaction with biomolecules, either by covalent binding or by complex formation, is essential for their antigenicity and immunogenicity. However, contact allergens are very special due to their ability to simultaneously activate the innate immune system and to form $\mathrm{T}$ cell epitopes.

The formation of $\mathrm{T}$ cell epitopes requires protein reactivity of contact allergens. They may directly bind to peptides presented by MHC molecules on the cell surface or, as is the case for metal ions, form complexes with peptides and MHC molecules or MHC molecules alone in a peptide-independent manner. In addition, extra- and intracellular proteins can be chemically modified and are then processed to generate contact allergen-modified peptides that are displayed on MHC molecules on the surface of antigen-presenting cells (APC) [10].

Another, essential consequence of the chemical reactivity of contact allergens is the activation of the innate immune system, a pre-requisite for the activation of the adaptive immune system [14,15]. Here, contact allergens are very peculiar since they engage pathways characteristic for innate immune responses to infections, and this can happen under sterile conditions. This special type of inflammation induced by xenobiotic substances was called xenoinflammation to distinguish it from microbial inflammation or auto-inflammation [14].

\section{The Innate Molecular Immune Response to Contact Allergens}

The surprising result of studies addressing the innate immune system activation by (the few analyzed) contact allergens was that they trigger the same signaling pathways that are triggered by infectious agents. During an infection, some pathogens activate pattern recognition receptors (PRRs) such as the membrane-associated Toll-like receptors (TLRs) and the cytosolic NOD-like receptor (NLR) NLRP3, a component of the caspase-1 activating NLRP3 inflammasome. These receptors recognize components of bacteria and viruses such as DNA or RNA, bacterial cell wall components or bacterial toxins commonly designated pathogen-associated molecular patterns (PAMPs), and they trigger the production of pro-inflammatory cytokines and chemokines. Vaccination against protein antigens 
usually requires the addition of such PAMPs commonly known as adjuvants. Infectious agents also trigger production of pro-inflammatory reactive oxygen species (ROS) which promote TLR and NLRP3 inflammasome activation. As mentioned above, contact allergens are very peculiar: they can activate both the innate and the adaptive immune system, i.e., they possess auto-adjuvant activity. In recent years, significant progress has been made in the elucidation of the mechanistic basis for this special feature of contact allergens. Contact allergens efficiently activate PRRs. For the TLRs, direct and indirect activation has been shown. The metal ions nickel and cobalt directly bind to conserved histidine residues in the human lipopolysaccharide (LPS) receptor TLR4, causing its dimerization and signaling in the absence of the cognate ligand LPS [16,17]. These histidine residues are missing in the mouse TLR4, which explains the failure of nickel to induce ACD in the mouse contact hypersensitivity (CHS) model unless an adjuvant such as LPS is added. Organic chemicals such as oxazolone and 2,4,6-trinitrochlorobenzene (TNCB) activate TLR2 and TLR4 indirectly as shown in the CHS model [18]. They cause the degradation of the extracellular matrix component hyaluronic acid (HA). HA fragments can then activate these TLRs. In addition, they cause oxidative stress and activation of the antioxidant phase II response due to their induction of reactive oxygen species (ROS) [19,20]. All of these contact allergens activate the NLRP3 inflammasome. In the case of the organic chemicals, it was shown that this is mediated by causing cellular stress resulting in the release of ATP and, consequently, the triggering of inflammasome activation via the ATP receptor P2X7R [21].

Another signling pathway triggered by contact allergens involves unknown receptors that couple to the kinase Syk [22]. It was shown that the production of IL-1 $\beta$ was mediated by signaling via the kinase Syk coupling to the adaptor CARD9 and Bcl10 for NF- $\mathrm{kB}$ activation. The processing of immature pro-IL-1 $\beta$ requires caspase- 1 activation via the NLRP3 inflammasome. This was dependent on ROS production but independent of CARD9/Bcl10 or the TLR/IL-1R-associated adaptor protein MyD88. This study implies that contact allergens directly or indirectly engage an as-yet-unknown immunoreceptor tyrosine-based activation motif (ITAM) containing a receptor that signals via Syk.

\section{The Innate Cellular Immune Response to Contact Allergens}

Triggering of the innate immune response by contact allergens does not only involve the activation of hematopoietic cells. Structural skin cells such as keratinocytes and dermal fibroblasts participate in the immune response. They express PRRs such as the hematopoietic cells. The interplay of many different skin resident and migratory cell types orchestrates the innate inflammatory response in a highly dynamic process. One example of such an interplay is the cross-talk between mast cells, neutrophils and DCs in the sensitization phase of ACD. The use of genetically engineered mouse strains which lack mast cells or allow for mast cell depletion has revealed their important pro-inflammatory role in CHS [23]. Depletion before sensitization or lack of mast cells strongly reduced ear-swelling responses to 2,4-dinitrofluorobenzene (DNFB) or fluorescein isothiocyanate (FITC). It was then shown that neutrophils which infiltrate the skin in CHS also have an important pro-inflammatory role [24]. In the absence of mast cells their skin infiltration was compromised. Moreover, DCs failed to efficiently migrate to skin-draining lymph nodes, and T cell priming was abrogated. In addition, neutrophils were also required in the elicitation phase of CHS in order to enable T cell recruitment to the inflamed skin. It remains to be shown how mast cells and neutrophils are activated by contact allergens. Also, PRRs may play a role here as recently demonstrated for TLR-dependent neutrophil activation in graft-versus-host disease [25]. Interestingly, a recent study revealed that neutrophils leave chemokine cues for $\mathrm{T}$ cell migration in the airways. In an influenza infection model, the authors demonstrated CXCR4-dependent CD8 ${ }^{+} \mathrm{T}$ cell migration along trails of packed CXCL12 [26]. Moreover, the effector function of the T cells was impaired in the absence of neutrophils, as was proliferation in another study demonstrating neutrophil migration to lymph nodes in a bacterial skin infection model [27]. Thus, infiltrated neutrophils may help to guide T cells into inflamed tissue sites and modulate $\mathrm{T}$ cell function. 


\section{Identification of Contact Allergens by in Vitro Assays: Alternatives to Animal Testing}

Key events of skin sensitization by chemicals have been summarized in the Adverse Outcome Pathway (AOP) [28,29]. Replacement of animal testing for the assessment of the skin-sensitizing potential of chemicals has resulted in the development of in vitro assays which cover the different steps of the AOP. The outcome of these efforts should be the development of an integrated testing strategy (ITS) that combines several assays [30-34]. Up to now, two in vitro assays have been fully validated and are now OECD guideline tests. The Direct Peptide Reactivity Assay (DPRA, OECD guideline test 442C) detects the chemical reactivity of test substances based on the depletion of model peptides that contain lysine or cysteine residues. Covalent binding of contact allergens causes a mass shift and disappearance of the mass peak of the unmodified peptide. The second assay is the Keratinosens assay (OECD guideline test 442D). This assay is based on the activation of the antioxidant phase 2 response $[35,36]$ and detects the activation of the transcription factor Nrf2 in a luciferase reporter system in the human keratinocyte cell line HaCaT. A third test under revision for final validation is the human cell line activation test (h-CLAT). In this assay, human monocytic leukemia THP-1 cells are stimulated by test chemicals and the upregulation of the costimulatory molecule CD86 is detected by flow cytometry. The combination of different assays and mathematical models in an ITS is underway and may increase the accuracy and predicitivity [37-39].

In this field of immunotoxicology, profiling efforts are undertaken to identify genetic or proteomic contact allergen-specific signatures for sensitization that can be used in in vitro assays. Examples are the gene signature identified in the human keratinocyte cell line HaCaT $[40,41]$, the identification of CREM and CCR2 using human DCs derived from CD34 ${ }^{+}$progenitors [42], the identification of a larger gene signature in human MUTZ-3 progenitor cells [43] and the analysis of genes regulated in sensitized human and mouse skin [44].

\section{Heterologous Innate Immune Stimulation}

The hazard and risk assessement in the mouse local lymph node assay (OECD TG 429), the gold standard for contact allergen identification, as well as the current hazard identification in in vitro assays, is performed with single substances. However, final products are usually mixtures and formulations containing a number of different substances, among them several contact allergens, detergents and preservatives. It has to be considered that such combinations may facilitate chemical penetration into the skin, thereby increasing local concentrations. In addition, the combination of contact allergens or of contact allergens and irritants may lead to synergistic or additive effects that amplify innate immune and stress responses (Figure 1A,B) [45-47]. This may lead to sensitizations not observed with single compounds which can be explained mechanistically $[48,49]$. A recent report showed no such effects in the Local Lymph Node Assay (LLNA) when isoeugenol and eugenol, two weak fragrance allergens, were mixed. Only dose addition was observed [50]. However, as the authors stated themselves, the effects on the contact allergen-specific $\mathrm{T}$ cell response have to be analyzed. There, one may see additive or synergisitc effects.

A good example for such augmentation effects is the TLR system. Of the 10 human and 13 mouse TLRs, most signal via the adaptor protein MyD88 to activate NF- $\mathrm{B}$. Therefore, simultaneous direct or indirect triggering of different TLRs by contact allergens may result in the amplification of inflammation. This may explain additive or synergistic effects as seen with mixtures and formulations. It is also possible to substitute for a missing innate immune stimulus not given by weak contact allergens by providing a heterologous stimulus by other contact allergens or even by infection (Figure 1C). In our CHS model, we have previously shown that mice lacking both TLR2 and TLR4 or TLR4 and IL-12R $\beta 2$ are resistant to CHS. However, triggering of TLR9 on DCs or by injection of synthetic TLR9 ligands into the skin of mice prior to sensitization with TNCB restored CHS ([18] and unpublished data).

These findings show the importance of the concept of heterologous innate immune stimulation [48]. A simplified view is that for the DC, it does not matter by which stimuli it is activated. As long as proper DC activation and polarization occurs to allow for the priming of contact 
allergen-specific T cells, it does not matter whether the contact allergen that is recognized by the $\mathrm{T}$ cells has provided autologous innate immune stimulation at all or whether it is sufficiently strong. Heterologous innate immune stimuli, as given by other contact allergens or ingredients of formulations and mixtures or even by infections, can provide additive or synergistic effects (Figure 1B) or even fully substitute for missing autologous stimuli (Figure 1C) [48,49].
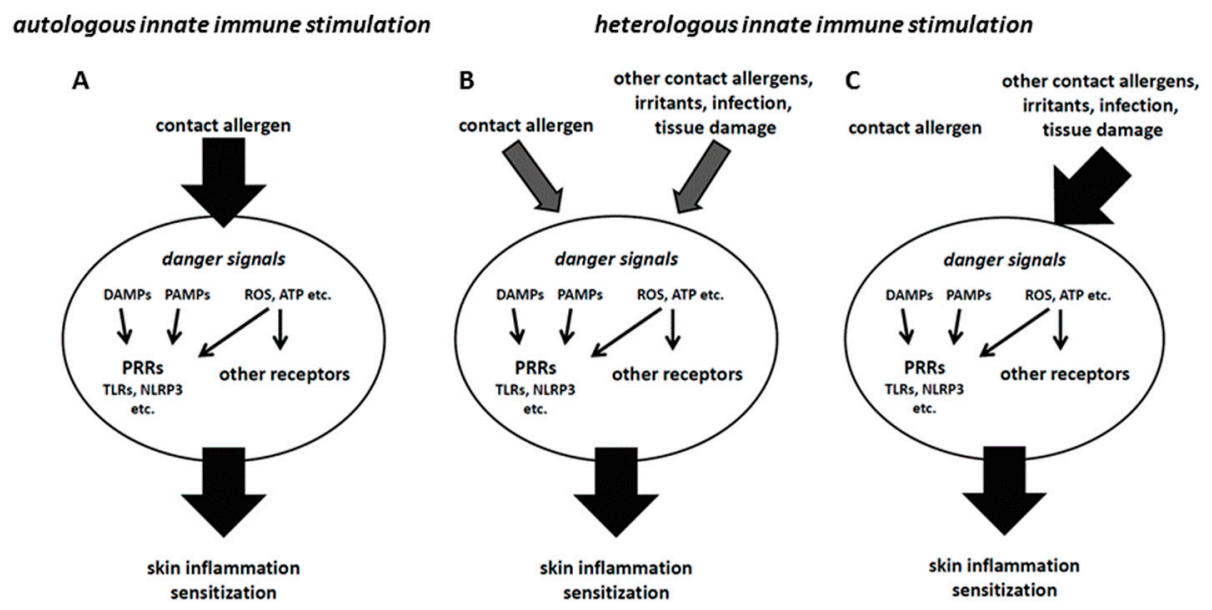

Figure 1. (A) If contact allergens trigger a sufficiently strong innate immune response, sensitization can occur (autologous innate immune stimulation). (B) Weaker contact allergens may only trigger an insufficient innate immune response that precludes sensitization. In this case, combination with other contact allergens or irritants, danger signals generated by tissue damage or an infection may provide heterologous innate immune stimulation that, via additive or synergistic effects, enables sufficient skin inflammation to allow for sensitization. (C) In some cases, contact allergens may fail to provide autologous innate immune stimulation, but still form $\mathrm{T}$ cell epitopes. In that case, heterologous innate immune stimulation can substitute for the missing stimulation by the contact allergen against which the $\mathrm{T}$ cell response is directed.

\section{Conclusions}

ACD and ICD are important inflammatory skin diseases with great socio-economic impact. The elucidation of the molecular and cellular pathomechanisms is moving forward and provides essential mechanistic insights. This is the basis for mechanism-based toxicological research and in vitro assay development to replace animal testing for contact allergen identification and for the identification of novel drug targets and the resulting design of targeted causative therapies. Biomarker discovery will improve diagnosis and promote our mechanistic understanding of chemical-induced skin disease.

Acknowledgments: The following grants were received in support of the own research work cited here: European Union EU Project Sens-it-iv, COLIPA/Cosmetics Europe and Research Commission of the Medical Faculty, Medical Center, University of Freiburg to Stefan F. Martin.

Conflicts of Interest: The author declares no conflict of interest. 


\section{Abbreviations}

$\begin{array}{ll}\text { ACD } & \text { allergic contact dermatitis } \\ \text { CHS } & \text { contact hypersensitivity } \\ \text { DC } & \text { dendritic cell } \\ \text { ICD } & \text { irritant contact dermatitis } \\ \text { NLR } & \text { NOD-like receptor } \\ \text { PAMP } & \text { pathogen associated molecular pattern } \\ \text { PRR } & \text { pattern recognition receptor } \\ \text { ROS } & \text { reactive oxygen species } \\ \text { TLR } & \text { Toll-like receptor }\end{array}$

\section{References}

1. Karlberg, A.T.; Borje, A.; Duus Johansen, J.; Liden, C.; Rastogi, S.; Roberts, D.; Uter, W.; White, I.R. Activation of non-sensitizing or low-sensitizing fragrance substances into potent sensitizers-Prehaptens and prohaptens. Contact Dermat. 2013, 69, 323-334. [CrossRef] [PubMed]

2. Peiser, M.; Tralau, T.; Heidler, J.; Api, A.M.; Arts, J.H.; Basketter, D.A.; English, J.; Diepgen, T.L.; Fuhlbrigge, R.C.; Gaspari, A.A.; et al. Allergic contact dermatitis: epidemiology, molecular mechanisms, in vitro methods and regulatory aspects. Current knowledge assembled at an international workshop at BfR, Germany. Cell. Mol. Life Sci. 2012, 69, 763-781. [CrossRef] [PubMed]

3. Brasch, J.; Becker, D.; Aberer, W.; Bircher, A.; Kranke, B.; Jung, K.; Przybilla, B.; Biedermann, T.; Werfel, T.; John, S.M.; et al. Guideline contact dermatitis: S1—Guidelines of the German Contact Allergy Group (DKG) of the German Dermatology Society (DDG), the Information Network of Dermatological Clinics (IVDK), the German Society for Allergology and Clinical Immunology (DGAKI), the Working Group for Occupational and Environmental Dermatology (ABD) of the DDG, the Medical Association of German Allergologists (AeDA), the Professional Association of German Dermatologists (BVDD) and the DDG. Allergo J. Int. 2014, 23, 126-138. [PubMed]

4. Holness, D.L. Occupational skin allergies: Testing and treatment (the case of occupational allergic contact dermatitis). Curr. Allergy Asthma Rep. 2014, 14. [CrossRef] [PubMed]

5. Wiszniewska, M.; Walusiak-Skorupa, J. Recent Trends in Occupational Contact Dermatitis. Curr. Allergy Asthma Rep. 2015, 15. [CrossRef] [PubMed]

6. Fyhrquist, N.; Lehto, E.; Lauerma, A. New findings in allergic contact dermatitis. Curr. Opin. Allergy Clin. Immunol. 2014, 14, 430-435. [CrossRef] [PubMed]

7. De Groot, A.C. New Contact Allergens: 2008 to 2015. Dermatitis 2015, 26, 199-215. [CrossRef] [PubMed]

8. Martin, S.F. Immunological mechanisms in allergic contact dermatitis. Curr. Opin. Allergy Clin. Immunol. 2015, 15, 124-130. [CrossRef] [PubMed]

9. Vocanson, M.; Hennino, A.; Rozieres, A.; Poyet, G.; Nicolas, J.F. Effector and regulatory mechanisms in allergic contact dermatitis. Allergy 2009, 64, 1699-1714. [CrossRef] [PubMed]

10. Martin, S.F.; Esser, P.R.; Schmucker, S.; Dietz, L.; Naisbitt, D.J.; Park, B.K.; Vocanson, M.; Nicolas, J.F.; Keller, M.; Pichler, W.J.; et al. T-cell recognition of chemicals, protein allergens and drugs: Towards the development of in vitro assays. Cell. Mol. Life Sci. 2010, 67, 4171-4184. [CrossRef] [PubMed]

11. Goubier, A.; Vocanson, M.; Macari, C.; Poyet, G.; Herbelin, A.; Nicolas, J.F.; Dubois, B.; Kaiserlian, D. Invariant NKT cells suppress $\mathrm{CD}^{+} \mathrm{T}$-cell-mediated allergic contact dermatitis independently of regulatory $\mathrm{CD}^{+}{ }^{\mathrm{T}}$ cells. J. Investig. Dermatol. 2013, 133, 980-987. [CrossRef] [PubMed]

12. Dhingra, N.; Shemer, A.; Correa da Rosa, J.; Rozenblit, M.; Fuentes-Duculan, J.; Gittler, J.K.; Finney, R.; Czarnowicki, T.; Zheng, X.; Xu, H.; et al. Molecular profiling of contact dermatitis skin identifies allergen-dependent differences in immune response. J. Allergy Clin. Immunol. 2014, 134, 362-372. [CrossRef] [PubMed]

13. Quaranta, M.; Knapp, B.; Garzorz, N.; Mattii, M.; Pullabhatla, V.; Pennino, D.; Andres, C.; Traidl-Hoffmann, C.; Cavani, A.; Theis, F.J.; et al. Intraindividual genome expression analysis reveals a specific molecular signature of psoriasis and eczema. Sci. Transl. Med. 2014, 6. [CrossRef] [PubMed] 
14. Martin, S.F. Allergic contact dermatitis: Xenoinflammation of the skin. Curr. Opin. Immunol. 2012, 24, 720-729. [CrossRef] [PubMed]

15. Kaplan, D.H.; Igyarto, B.Z.; Gaspari, A.A. Early immune events in the induction of allergic contact dermatitis. Nat. Rev. Immunol. 2012, 12, 114-124. [CrossRef] [PubMed]

16. Schmidt, M.; Raghavan, B.; Muller, V.; Vogl, T.; Fejer, G.; Tchaptchet, S.; Keck, S.; Kalis, C.; Nielsen, P.J.; Galanos, C.; et al. Crucial role for human Toll-like receptor 4 in the development of contact allergy to nickel. Nat. Immunol. 2010, 11, 814-819. [CrossRef] [PubMed]

17. Raghavan, B.; Martin, S.F.; Esser, P.R.; Goebeler, M.; Schmidt, M. Metal allergens nickel and cobalt facilitate TLR4 homodimerization independently of MD2. EMBO Rep. 2012, 13, 1109-1115. [CrossRef] [PubMed]

18. Martin, S.F.; Dudda, J.C.; Bachtanian, E.; Lembo, A.; Liller, S.; Durr, C.; Heimesaat, M.M.; Bereswill, S.; Fejer, G.; Vassileva, R.; et al. Toll-like receptor and IL-12 signaling control susceptibility to contact hypersensitivity. J. Exp. Med. 2008, 205, 2151-2162. [CrossRef] [PubMed]

19. Esser, P.R.; Wolfle, U.; Durr, C.; von Loewenich, F.D.; Schempp, C.M.; Freudenberg, M.A.; Jakob, T.; Martin, S.F. Contact sensitizers induce skin inflammation via ROS production and hyaluronic acid degradation. PLoS ONE 2012, 7, e41340. [CrossRef] [PubMed]

20. El Ali, Z.; Gerbeix, C.; Hemon, P.; Esser, P.R.; Martin, S.F.; Pallardy, M.; Kerdine-Romer, S. Allergic skin inflammation induced by chemical sensitizers is controlled by the transcription factor Nrf2. Toxicol. Sci. 2013, 134, 39-48. [CrossRef] [PubMed]

21. Weber, F.C.; Esser, P.R.; Muller, T.; Ganesan, J.; Pellegatti, P.; Simon, M.M.; Zeiser, R.; Idzko, M.; Jakob, T.;

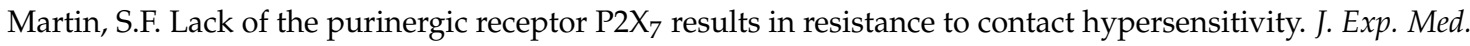
2010, 207, 2609-2619. [CrossRef] [PubMed]

22. Yasukawa, S.; Miyazaki, Y.; Yoshii, C.; Nakaya, M.; Ozaki, N.; Toda, S.; Kuroda, E.; Ishibashi, K.; Yasuda, T.; Natsuaki, Y.; et al. An ITAM-Syk-CARD9 signalling axis triggers contact hypersensitivity by stimulating IL-1 production in dendritic cells. Nat. Commun. 2014, 5. [CrossRef] [PubMed]

23. Dudeck, A.; Dudeck, J.; Scholten, J.; Petzold, A.; Surianarayanan, S.; Kohler, A.; Peschke, K.; Vohringer, D.; Waskow, C.; Krieg, T.; et al. Mast Cells Are Key Promoters of Contact Allergy that Mediate the Adjuvant Effects of Haptens. Immunity 2011, 34, 973-984. [CrossRef] [PubMed]

24. Weber, F.C.; Nemeth, T.; Csepregi, J.Z.; Dudeck, A.; Roers, A.; Ozsvari, B.; Oswald, E.; Puskas, L.G.; Jakob, T.; Mocsai, A.; et al. Neutrophils are required for both the sensitization and elicitation phase of contact hypersensitivity. J. Exp. Med. 2015, 212, 15-22. [CrossRef] [PubMed]

25. Schwab, L.; Goroncy, L.; Palaniyandi, S.; Gautam, S.; Triantafyllopoulou, A.; Mocsai, A.; Reichardt, W.; Karlsson, F.J.; Radhakrishnan, S.V.; Hanke, K.; et al. Neutrophil granulocytes recruited upon translocation of intestinal bacteria enhance graft-versus-host disease via tissue damage. Nat. Med. 2014, 20, 648-654. [CrossRef] [PubMed]

26. Lim, K.; Hyun, Y.M.; Lambert-Emo, K.; Capece, T.; Bae, S.; Miller, R.; Topham, D.J.; Kim, M. Neutrophil trails guide influenza-specific CD8 ${ }^{+} \mathrm{T}$ cells in the airways. Science 2015, 349. [CrossRef] [PubMed]

27. Hampton, H.R.; Bailey, J.; Tomura, M.; Brink, R.; Chtanova, T. Microbe-dependent lymphatic migration of neutrophils modulates lymphocyte proliferation in lymph nodes. Nat. Commun. 2015, 6. [CrossRef] [PubMed]

28. MacKay, C.; Davies, M.; Summerfield, V.; Maxwell, G. From pathways to people: Applying the adverse outcome pathway (AOP) for skin sensitization to risk assessment. ALTEX 2013, 30, 473-486. [CrossRef] [PubMed]

29. Maxwell, G.; MacKay, C.; Cubberley, R.; Davies, M.; Gellatly, N.; Glavin, S.; Gouin, T.; Jacquoilleot, S.; Moore, C.; Pendlington, R.; et al. Applying the skin sensitisation adverse outcome pathway (AOP) to quantitative risk assessment. Toxicol. Vitr. 2014, 28, 8-12. [CrossRef] [PubMed]

30. Leist, M.; Hasiwa, N.; Rovida, C.; Daneshian, M.; Basketter, D.; Kimber, I.; Clewell, H.; Gocht, T.; Goldberg, A.; Busquet, F.; et al. Consensus report on the future of animal-free systemic toxicity testing. ALTEX 2014, 31, 341-356. [CrossRef] [PubMed]

31. van der Veen, J.W.; Soeteman-Hernandez, L.G.; Ezendam, J.; Stierum, R.; Kuper, F.C.; van Loveren, H. Anchoring molecular mechanisms to the adverse outcome pathway for skin sensitization: Analysis of existing data. Crit. Rev. Toxicol. 2014, 44, 590-599. [CrossRef] [PubMed]

32. Wong, C.L.; Ghassabian, S.; Smith, M.T.; Lam, A.L. In vitro methods for hazard assessment of industrial chemicals-Opportunities and challenges. Front. Pharmacol. 2015, 6. [CrossRef] [PubMed] 
33. Reisinger, K.; Hoffmann, S.; Alepee, N.; Ashikaga, T.; Barroso, J.; Elcombe, C.; Gellatly, N.; Galbiati, V.; Gibbs, S.; Groux, H.; et al. Systematic evaluation of non-animal test methods for skin sensitisation safety assessment. Toxicol. Vitr. 2015, 29, 259-270. [CrossRef] [PubMed]

34. Urbisch, D.; Mehling, A.; Guth, K.; Ramirez, T.; Honarvar, N.; Kolle, S.; Landsiedel, R.; Jaworska, J.; Kern, P.S.; Gerberick, F.; et al. Assessing skin sensitization hazard in mice and men using non-animal test methods. Regul. Toxicol. Pharmacol. 2015, 71, 337-351. [CrossRef] [PubMed]

35. Hayes, J.D.; Dinkova-Kostova, A.T. The Nrf2 regulatory network provides an interface between redox and intermediary metabolism. Trends Biochem. Sci. 2014, 39, 199-218. [CrossRef] [PubMed]

36. Tebay, L.E.; Robertson, H.; Durant, S.T.; Vitale, S.R.; Penning, T.M.; Dinkova-Kostova, A.T.; Hayes, J.D. Mechanisms of activation of the transcription factor Nrf2 by redox stressors, nutrient cues, and energy status and the pathways through which it attenuates degenerative disease. Free Radic. Biol. Med. 2015, 88, 108-146. [CrossRef] [PubMed]

37. Bauch, C.; Kolle, S.N.; Ramirez, T.; Eltze, T.; Fabian, E.; Mehling, A.; Teubner, W.; van Ravenzwaay, B.; Landsiedel, R. Putting the parts together: Combining in vitro methods to test for skin sensitizing potentials. Regul. Toxicol. Pharmacol. 2012, 63, 489-504. [CrossRef] [PubMed]

38. Natsch, A.; Ryan, C.A.; Foertsch, L.; Emter, R.; Jaworska, J.; Gerberick, F.; Kern, P. A dataset on 145 chemicals tested in alternative assays for skin sensitization undergoing prevalidation. J. Appl. Toxicol. 2013, 33, 1337-1352. [CrossRef] [PubMed]

39. van der Veen, J.W.; Rorije, E.; Emter, R.; Natsch, A.; van Loveren, H.; Ezendam, J. Evaluating the performance of integrated approaches for hazard identification of skin sensitizing chemicals. Regul. Toxicol. Pharmacol. 2014, 69, 371-379. [CrossRef] [PubMed]

40. Vandebriel, R.J.; Pennings, J.L.; Baken, K.A.; Pronk, T.E.; Boorsma, A.; Gottschalk, R.; Van Loveren, H. Keratinocyte gene expression profiles discriminate sensitizing and irritating compounds. Toxicol. Sci. 2010, 117, 81-89. [CrossRef] [PubMed]

41. van der Veen, J.W.; Pronk, T.E.; van Loveren, H.; Ezendam, J. Applicability of a keratinocyte gene signature to predict skin sensitizing potential. Toxicol. Vitr. 2013, 27, 314-322. [CrossRef] [PubMed]

42. Lambrechts, N.; Nelissen, I.; Van Tendeloo, V.; Witters, H.; Van Den Heuvel, R.; Hooyberghs, J.; Schoeters, G. Functionality and specificity of gene markers for skin sensitization in dendritic cells. Toxicol. Lett. 2011, 203, 106-110. [CrossRef] [PubMed]

43. Johansson, H.; Albrekt, A.S.; Borrebaeck, C.A.; Lindstedt, M. The GARD assay for assessment of chemical skin sensitizers. Toxicol. Vitr. 2013, 27, 1163-1169. [CrossRef] [PubMed]

44. Cottrez, F.; Boitel, E.; Auriault, C.; Aeby, P.; Groux, H. Genes specifically modulated in sensitized skins allow the detection of sensitizers in a reconstructed human skin model. Development of the SENS-IS assay. Toxicol. Vitr. 2015, 29, 787-802. [CrossRef] [PubMed]

45. Agner, T.; Johansen, J.D.; Overgaard, L.; Volund, A.; Basketter, D.; Menne, T. Combined effects of irritants and allergens. Synergistic effects of nickel and sodium lauryl sulfate in nickel—Sensitized individuals. Contact Dermat. 2002, 47, 21-26. [CrossRef]

46. Pedersen, L.K.; Johansen, J.D.; Held, E.; Agner, T. Augmentation of skin response by exposure to a combination of allergens and irritants-A review. Contact Dermat. 2004, 50, 265-273. [CrossRef] [PubMed]

47. Bonefeld, C.M.; Nielsen, M.M.; Rubin, I.M.; Vennegaard, M.T.; Dabelsteen, S.; Gimenez-Arnau, E.; Lepoittevin, J.P.; Geisler, C.; Johansen, J.D. Enhanced sensitization and elicitation responses caused by mixtures of common fragrance allergens. Contact Dermat. 2011, 65, 336-342. [CrossRef] [PubMed]

48. Martin, S.F. Adaptation in the innate immune system and heterologous innate immunity. Cell. Mol. Life Sci. 2014, 71, 4115-4130. [CrossRef] [PubMed]

49. Martin, S.F. New concepts in cutaneous allergy. Contact Dermat. 2015, 72, 2-10. [CrossRef] [PubMed]

50. Kienhuis, A.S.; Slob, W.; Gremmer, E.R.; Vermeulen, J.P.; Ezendam, J. A Dose-Response Modeling Approach Shows That Effects From Mixture Exposure to the Skin Sensitizers Isoeugenol and Cinnamal Are in Line With Dose Addition and Not With Synergism. Toxicol. Sci. 2015, 147, 68-74. [CrossRef] [PubMed]

(C) 2016 by the author; licensee MDPI, Basel, Switzerland. This article is an open access article distributed under the terms and conditions of the Creative Commons by Attribution (CC-BY) license (http:/ / creativecommons.org/licenses/by/4.0/). 